\title{
School-based interventions for teen dating violence prevention: integrative literature review
}

\author{
Intervenções na escola para prevenção da violência nas relaçôes de intimidade entre \\ adolescentes: revisão integrativa da literatura \\ Intervenciones en la escuela para prevenir la violencia en las relaciones íntimas entre \\ adolescentes: revisión integradora de la literatura \\ Diene Monique Carlos*; Ana Beatriz Campeiz**; Jorge Luiz da Silva**; Maria Isabel Domingues Fernandes ${ }^{* * * *}$; \\ Maria Neto da Cruz Leitão*****; Marta Angelica Iossi Silva******; Maria das Graças Carvalho Ferriani*******
}

\begin{abstract}
Background: Intimate partner violence (IPV) in adolescence is a more serious problem because it negatively impacts the healthy development and is a precursor to domestic and family violence.

Objectives: To identify the types of primary IPV prevention interventions that have been implemented in school settings. Methodology: Integrative literature review in the following databases: PubMed, CINAHL, Lilacs, and SciELO virtual library.

Results: Twelve studies were included in this review. Interventions were identified based on 3 categories: Multicomponent interventions; Skill-building interventions; and Theater/role-playing interventions. Similar results were found in all studies. Population and approach specificities were discussed.

Conclusion: In this review, important contributions to IPV prevention interventions were presented, such as the need for theoretical background, life-context approach, and intervention towards bystanders.
\end{abstract}

Keywords: intimate partner violence; adolescent; primary prevention; school nursing; review literature as topic

\section{Resumo}

Enquadramento: A violência nas relaçōes de intimidade (VRI) quando ocorre na adolescência configura-se como um problema considerado mais grave por impactar negativamente o desenvolvimento saudável e por se constituir prenunciador da violência conjugal e intrafamiliar.

Objetivos: Identificar os tipos de intervenção de prevençáo primária da VRI entre adolescentes que têm sido implementados em contexto escolar.

Metodologia: Revisão integrativa de literatura nas bases PubMed, CINAHL, Lilacs, e na biblioteca virtual SciELO.

Resultados: Doze estudos compuseram a presente revisão. As intervençōes foram identificadas por meio de 3 categorias, multicomponentes, direcionadas ao desenvolvimento de habilidades, e baseadas em teatro/dramatização. Os estudos apresentaram resultados homogéneos. Especificidades de população e abordagem foram discutidas.

Conclusão: Importantes contribuiçôes para delineamento das intervençóes de prevenção da VRI foram apresentadas, como a necessidade de embasamento teórico; aproximação do contexto de vida dos adolescentes e trabalho junto aos expectadores.

Palavras-chave: violência por parceiro íntimo; adolescente; prevençáo primária; serviços de enfermagem escolar; literatura de revisão como assunto

*Ph.D., RN, College of Nursing, University of São Paulo at Ribeirão Preto, 14040-902, Ribeirão Preto, São Paulo, Brazil [diene_enf@hotmail.com].Contribution to the article: project design and elaboration; database lo, Brazil [diene_enf@hotmail.com]. Contribution to the article: project design and elaboration; database
search; analysis and interpretation of article review; final approval for publication. Address for correspondence: Avenida dos Bandeirantes, 3900, Monte Alegre, 14040-902, Ribeirāo Preto, Brazil.

* Socition São interpretaion

Thy of São Paulo at Ribeirão Preto, 14040-902, Ribeirão

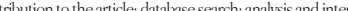
Preto, Sao Paulo, Brazil [jorgelsilva@usp.br].Contribution

* pretation of article review; final approval for publication. Contribution to the article: project design and elaboration; critical revision of the article; final approval for publication.

******: Ph.D. Professor Nursing School of Coimbra, 3046-851, Coimbm, Portugal [mneto@esenfc pt]. Contribution to the article: project desion and elaboration; critical revision of the article; final approval for

publication.
$* * * * * * *$ Ph.D., Professor, College of Nursing, University of São Paulo at Ribeirão Preto, 14040-902, Ribeirão Preto,São Paulo, Brazil [maiossi@eerp.usp.br]. Contribution to the article: critical revision of the article, final approval for publication

********Ph.D., Professor, College of Nursing, University of São Paulo at Ribeirão Preto, 14040902, Ribeirão Preto,São Paulo,Brazil [caroline@eerp.usp.br. Contribution to the article: project design and elaboration; final critical revision of the article; final approval for publication.

\section{Resumen}

Marco contextual: Cuando la violencia en las relaciones íntimas (VRI) se produce en la adolescencia, supone un problema considerado más grave, ya que impacta negativamente en el desarrollo sano y constituye una señal previa de violencia conyugal e intrafamiliar.

Objetivos: Identificar los tipos de intervención de prevención primaria de la VRI entre adolescentes que se han implementado en el contexto escolar.

Metodología: Revisión integradora de la literatura en las bases PubMed, CINAHL, Lilacs, y en la biblioteca virtual SciELO.

Resultados: La presente revisión comprendió doce estudios. Las intervenciones se identificaron a través de 3 categorías, multicomponentes, dirigidas al desarrollo de habilidades, y basadas en el teatro/la dramatización. Los estudios presentaron resultados homogéneos. Se discutieron las especificidades de la población y el enfoque.

Conclusión: Se presentaron importantes contribuciones para diseñar las intervenciones de prevención de la VRI, como la necesidad de una base teórica; la aproximación del contexto de vida de los adolescentes y el trabajo junto a los espectadores.

Palabras clave: violencia de pareja; adolescente; prevención primaria; servicios de enfermería escolar; literatura de revisión como assunto 


\section{Introduction}

Intimate partner violence (IPV) occurs between two people in a close relationship and can be physical, emotional or sexual. Stalking has been put forward as another form of IPV, particularly among adolescents and refers to a threatening and controlling pattern that causes fear in the victim. Violence may be a single act or a series of continuous acts perpetrated by one or both partners in homosexual or heterosexual couples. This type of violence may occur in different stages of human development: adolescence, adulthood, and old age (Centers for Disease Control and Prevention [CDC], 2016).

However, this type of violence in adolescence is a more serious problem because it negatively impacts the healthy development and is a precursor to domestic and family violence (World Health Organization [WHO], 2014). Several studies point to the complexity of IPV, particularly due to its impact on the physical, psychological, and social development. Antisocial trends that promote aggressive interactions, use of psychoactive substances, depression, and suicidal ideation are generally associated with experiences of IPV among adolescents (Williams et al., 2014; Póo \& Vizcarra, 2011).

According to the $\mathrm{WHO}$, although all levels of care are important, violence prevention receives little international attention, investment, and commitment when compared to other levels (WHO, 2014). Prevention programs show that IPV can be prevented by engaging multiple stakeholders with multiple approaches, with the purpose of unveiling risk factors for violence, including social norms that promote gender inequality and violence, and factors that support the development of non-violent behaviors (Ellsberg et al., 2015).

The literature on IPV prevention interventions is growing. School is a privileged setting for these initiatives because it is the first environment where young people experience their identities apart from their families (Malta et al., 2015).

In view of the above, this study aims to identify primary IPV prevention interventions that have been implemented in school settings. After identifying the types of interventions, the authors will describe the influencing factors. This study is justified by the need to understand the interventions that, within this scope, may guide health care practices, as well as increase the attention to IPV prevention, as recommended by the WHO and the scientific literature (WHO, 2014; Ellsberg et al., 2015; Póo \& Vizcarra, 2011).

\section{Methodological procedures of inte- grative review}

To achieve the objective set out, the search method used was the integrative literature review, which analyzes the relevant searches that support decision-making and the improvement of clinical practice, allowing the synthesis of the state-of-the-art on a given topic, as well as the identification of knowledge gaps that need to be addressed with new studies (Mendes, Silveira, \& Galvão, 2008). The following steps were defined: (1) identification of the problem; (2) selection of articles; (3) categorization of studies; (4) interpretation of results; and (5) synthesis of knowledge produced (Mendes et al., 2008).

Step 1 - Bearing in mind the issues addressed in this study, the following guiding question was formulated: Which interventions for primary IPV prevention have been implemented in school settings? This question was formulated based on the PICO strategy: the population was composed of adolescents aged 10 to 19 years, according to WHO guidelines (WHO, 2017); this review included all studies with people in this age group, even if they also considered young adults; the phenomenon of interest was primary IPV prevention interventions; and the context was the school (middle and high schools and universities). The results were analyzed from an exploratory perspective.

Step 2 - The search was conducted between 20 and 22 April, 2016, in the following databases: PubMed, CINAHL (Cumulative Index to Nursing and Allied Health Literature), LILACS (Latin American and Caribbean Health Sciences), and SciELO (Scientific Electronic Library Online), using the timeframe between $01 / 01 / 2011$ and $31 / 12 / 2015$. This timeframe was established with the purpose of finding studies developed over the past 5 years. These sources were selected due to the multidisciplinary nature of the studies, at both national and international levels. The selected descriptors in PubMed were MeSH terms (Medical Subject Heading) and Subheadings: adolescent AND intimate partner violence $\mathrm{OR}$ dating abuse $\mathrm{OR}$ dating violence $\mathrm{OR}$ sexual harassment $\mathrm{AND}$ primary prevention OR health promotion OR school based services OR prevention and control. In the CINAHL database, the following headings were used: adolescence OR adolescent health AND intimate partner violence $\mathrm{OR}$ dating violence $\mathrm{OR}$ sexual harassment AND health promotion. In LILACS and SciELO databases, Health Sciences Descriptors were used: adolescente (adoloscent) AND violência por parceiro intimo (intimate partner violence) AND prevenção primária 
(primary prevention) OR promoção da saúde (health promotion) OR saúde escolar (school health). The strategies used to select the articles identified in the search followed the study proposal and the following inclusion criteria: a timeframe of 5 years (2011-2015); languages of publication (English, Portuguese, and Spanish); type of scientific production (only primary scientific articles); studies exclusively focused on primary IPV prevention interventions in school settings. Other academic productions, such as theses, dissertations, monographs, and literature reviews were excluded.

The titles and abstracts of all articles identified in the online search were analyzed, eliminating possible duplicates across the search results or between the databases and the online library.
Then, the titles and abstracts were analyzed and those studies that did not refer to the study object were excluded. The original articles were retrieved and read in full, restricting the corpus of analysis. Based on this analysis, the study topics, the implemented prevention programs, and the obtained results were identified and later categorized. Articles that did not address the study object were excluded, mainly because they were not directed to adolescents, were not primary prevention intervention, or had not been developed in school settings. This selection process is outlined in the flow chart (Figure 1). It should be emphasized that these steps were performed by two independent reviewers, and a third reviewer was available in case of disagreements about the inclusion or exclusion of studies.

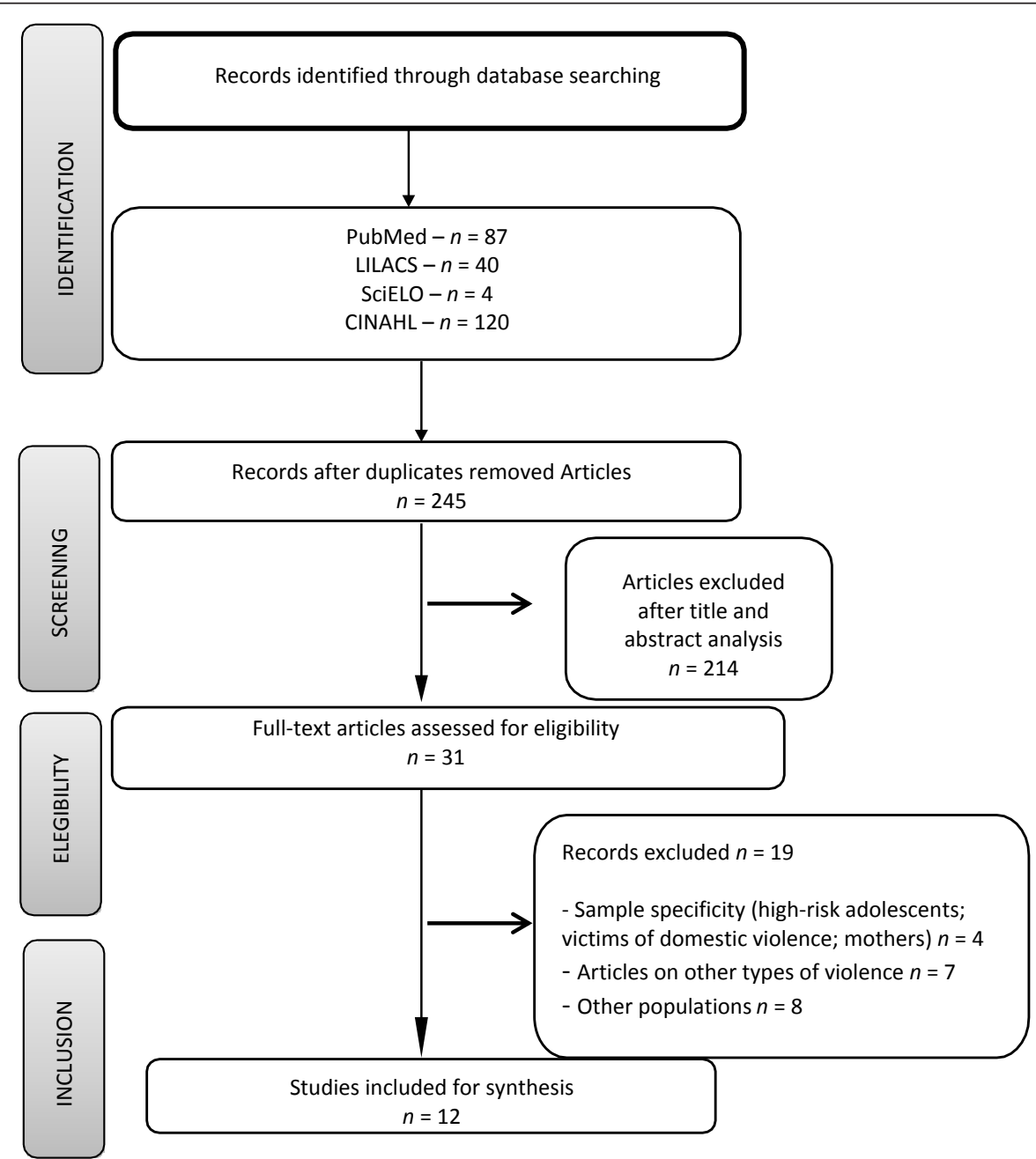

Figure 1. Flow chart of the methodological steps used in the integrative review. 
Steps 3 and 4 - A specific instrument was designed to extract data from the selected articles into a MS Excel 2010 sheet, namely: data on the article (year of publication, country, journal, authors and study area, study objectives, type of study, study setting, study subjects, data collection instruments, data analysis), implemented interventions and obtained results. Based on the critical and analytical reading of the material, the study topics were identified: implemented programs, areas of intervention, and synthesis of results. These elements were synthesized in the explored categories.

Step 5 - After interpretation of the results in the explored categories, a summary was per- formed of the knowledge produced from the literature review.

\section{Results and interpretation}

The bibliometric indicators of the selected studies are shown in Table 1.

As shown in Table 1, a total of 12 articles were found. Most of them were published in 2015 in the United States of America (USA). The quantitative methodological approach was predominant. The study settings were predominantly basic and secondary schools, but three studies were also carried out at universities.

Table 1

Bibliometric indicators of studies selected for the integrative review

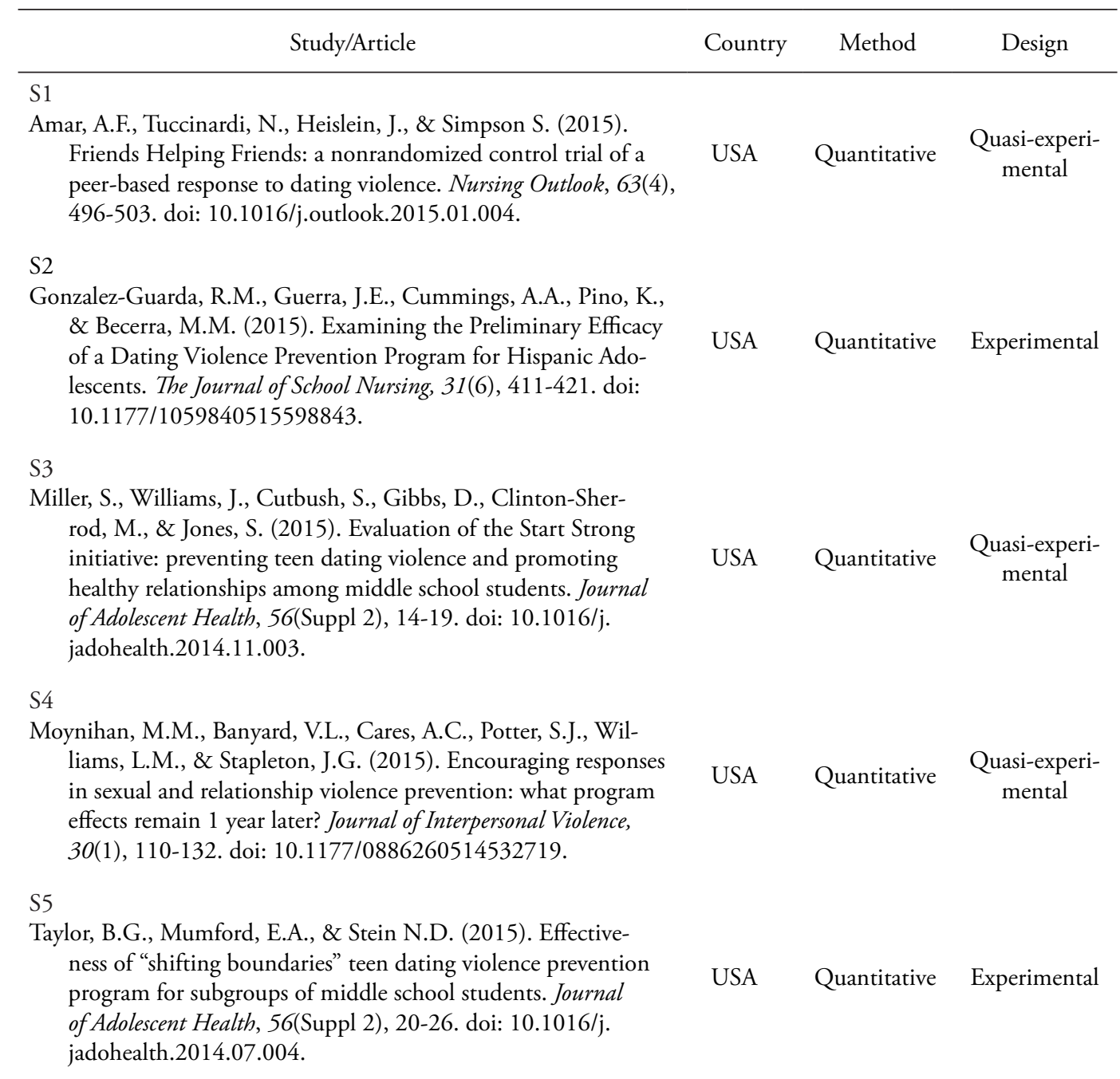


S6

Williams, J., Miller, S., Cutbush, S., Gibbs, D., Clinton-Sherrod, M., \& Jones S. (2015). A Latent Transition Model of the Effects of a Teen Dating Violence Prevention Initiative. Journal of Adolescent Health, 56(Suppl 2), 27-32. doi: 10.1016/j. jadohealth.2014.08.019.

S7

Miller, E., Das, M., Tancredi, D.J., McCauley, H.L., Virata, M.C., Nettiksimmons, J., ... Verma, R. (2014). Evaluation of a gender-based violence prevention program for student athletes in Mumbai, India. Journal of Interpersonal Violence, 29(4), 758778. doi: 10.1177/0886260513505205.

S8

Belknap, R.A., Haglund, K., Felzer, H., Pruszynski, J., \& Schneider, J. (2013). A Theater Intervention to Prevent Teen Dating Violence for Mexican-American Middle School Students Journal of Adolescent Health, 53(1), 62-67. doi: 10.1016/j. jadohealth.2013.02.006.

S9

Miller, E., Tancredi, D.J., McCauley, H.L., Decker, M.R., Virata, M.C., Anderson, H.A., ... Silverman J.G. (2013). One-year follow-up of a coach-delivered dating violence prevention program: a cluster randomized controlled trial. American Journal of Preventive Medicine, 45(1), 108-112. doi: 10.1016/j. amepre.2013.03.007.

S10

Murta, S. G., Santos, B.R.P. dos, Nobre, L.A., Araújo, I.F. de, Miranda, A.A.V., Rodrigues, Í.O., \& Franco, C.T.P. (2013). Prevenção à violência no namoro e promoçáo de habilidades de vida em adolescentes. Psicologia USP, 24(2), 263-288. Retrieved from: https://dx.doi.org/10.1590/S010365642013000200005

S11

Miller, E., Tancredi, D.J., McCauley, H.L., Decker, M.R., Virata, M.C., Anderson, H.A.,... Silverman, J.G. (2012). "Coaching boys into men": a cluster-randomized controlled trial of a dating violence prevention program. Journal of Adolescent Health, 51(5), 431-438. doi: 10.1016/j.jadohealth.2012.01.018.

S12

Póo, A.M., \& Vizcarra, M.B. (2011). Diseño, Implementación y Evaluación de un Programa de Prevención de la Violencia en el Noviazgo. Terapia psicológica, 29(2), 213-223. Retrieved from: https://dx.doi.org/10.4067/S0718-48082011000200008
USA Quantitative Quasi-experimental

India Quantitative Quasi-experimental

USA

Mixed

Pre- and Posttest

Brazil

Quantitative

Quasi-experimental

Experimental
Quasi-experimental

To synthesize the information and facilitate consultation, Table 2 was designed to include the context, population, and main results. 
Table 2

Summary of the included studies

\begin{tabular}{llll}
\hline Study & \multicolumn{1}{c}{ Context } & \multicolumn{1}{c}{ Population } & \multicolumn{1}{c}{ Main results } \\
\hline S1 & $\begin{array}{l}\text { One } \\
\text { university }\end{array}$ & $\begin{array}{l}\text { 101 female adoles- } \\
\text { cents and young } \\
\text { adults aged } 18 \text { to } 22 \\
\text { years }\end{array}$ & $\begin{array}{l}\text { The participants in the intervention group showed increased } \\
\text { responsibility and intention to help }(p<0.05) \text { and decreased } \\
\text { rape myth acceptance }(p<0.05) .\end{array}$ \\
S2 & $\begin{array}{l}\text { One public } \\
\text { school }\end{array}$ & $\begin{array}{l}\text { 82 adolescents aged } \\
13 \text { to 16 years }\end{array}$ & $\begin{array}{l}\text { The intervention produced no significant effects over time on } \\
\text { victimization and aggression in dating, when controlling for } \\
\text { gender and gender interaction. }\end{array}$ \\
\hline
\end{tabular}

\begin{tabular}{|c|c|c|c|}
\hline S3 & Eight schools & $\begin{array}{l}1517 \text { adolescents } \\
\text { aged } 11 \text { to } 14 \text { years }\end{array}$ & $\begin{array}{l}\text { No significant differences were found between victimization } \\
\text { and IPV. However, a significant increase was found in par- } \\
\text { ent-child communication }(p<0.001) \text { and in satisfaction and } \\
\text { support in the dating relationship }(p<0.001) \text {. Gender stereo- } \\
\text { types }(p<0.001) \text { and acceptance of dating violence }(p<0.01) \\
\text { also decreased, without losing significance over time. }\end{array}$ \\
\hline S4 & $\begin{array}{l}\text { Two } \\
\text { universities } \\
\text { (one rural and } \\
\text { one urban) }\end{array}$ & $\begin{array}{l}948 \text { adolescents and } \\
\text { young adults aged } \\
18 \text { to } 24 \text { years }\end{array}$ & $\begin{array}{l}\text { The intervention group reported positive changes in help be- } \\
\text { haviors in situations of violence; however, the levels were not } \\
\text { statistically significant. }\end{array}$ \\
\hline S5 & 30 schools & $\begin{array}{l}2665 \text { adolescents in } \\
\text { grades } 6-7\end{array}$ & $\begin{array}{l}\text { There were significant reductions in the frequency of IPV, both } \\
\text { for victimization (IRR: } 0.46 ; 95 \% \text { CI: } 0.25-0.42 ; p=0.01 \text { ) and } \\
\text { aggression (IRR: } 0.50 ; 95 \% \text { CI: } 0.25-0.93 ; p=0.027 \text { ). }\end{array}$ \\
\hline
\end{tabular}

In the most problematic group, which covered participation in

S6 Eight schools $\begin{aligned} & 1517 \text { adolescents } \\ & \text { aged } 11 \text { to } 14 \text { years }\end{aligned}$
the three problems under analysis (IPV, bullying, and sexual harassment), the intervention led to a reduction in behaviors, although there was no reduction in IPV alone. The program was more beneficial for students with more severe problematic profiles and improved their transition to less severe behavioral profiles.

\begin{tabular}{|c|c|c|c|}
\hline S7 & $\begin{array}{l}16 \text { basic edu- } \\
\text { cation schools }\end{array}$ & $\begin{array}{l}309 \text { male adolescent } \\
\text { athletes aged } 10 \text { to } \\
16 \text { years }\end{array}$ & $\begin{array}{l}\text { Although the athletes who participated in this intervention } \\
\text { improved their gender-equitable attitudes, the levels were not } \\
\text { statistically significant. There was also no difference in their } \\
\text { perceived sexual violence and intervention behaviors as by- } \\
\text { standers. }\end{array}$ \\
\hline S8 & $\begin{array}{l}\text { Two parochial } \\
\text { schools and } \\
\text { one public } \\
\text { school }\end{array}$ & $\begin{array}{l}668^{\text {th }} \text { grade adoles- } \\
\text { cents with a mean } \\
\text { age of } 13 \text { years }\end{array}$ & $\begin{array}{l}\text { Adolescents had less acceptance of IPV }(p<0.05) \text {, increased } \\
\text { confidence in their ability to resolve conflicts nonviolently } \\
(p<0.001) \text {, and greater intentions to use nonviolent strategies } \\
(p=0.001) \text {. Boys preferred to seek their father's assistance } \\
\text { in case of IPV, whereas girls sought their mother's assistance. } \\
\text { Following the parents' assistance, both male and female } \\
\text { adolescents reported seeking their friends' assistance. }\end{array}$ \\
\hline S9 & $\begin{array}{l}16 \text { secondary } \\
\text { education } \\
\text { schools }\end{array}$ & $\begin{array}{l}1513 \text { male ado- } \\
\text { lescent athletes in } \\
\text { grades } 9-11\end{array}$ & $\begin{array}{l}\text { There was a higher reduction in IPV among athletes who par- } \\
\text { ticipated in the intervention group than among those who par- } \\
\text { ticipated in the control group (OR: } 0.15 ; 95 \% \text { CI: } 0.27-0.03) \text {. } \\
\text { Negative behaviors, such as laughing and going along with } \\
\text { a peer's abusive behaviors, also decreased in the intervention } \\
\text { group (OR: }-0.41 ; 95 \% \text { CI: } 0.72-0.10) \text {. No significant differ- } \\
\text { ences were found in gender-equitable attitudes, recognition of } \\
\text { abusive behaviors, and intention to intervene. }\end{array}$ \\
\hline
\end{tabular}




\begin{tabular}{|c|c|c|c|}
\hline S10 & $\begin{array}{l}\text { One second- } \\
\text { ary education } \\
\text { school }\end{array}$ & $\begin{array}{l}60 \text { adolescents aged } \\
14 \text { to } 18 \text { years }\end{array}$ & $\begin{array}{l}\text { The results showed a higher reduction in hostile and ho- } \\
\text { mophobic beliefs and responses, as well as a higher increase in } \\
\text { non-sexist and non-homophobic responses among the partici- } \\
\text { pants in the intervention group than the control group. In the } \\
5 \text {-month follow-up assessment after the intervention, only } 42 \% \\
\text { of the adolescents reported having implemented what they had } \\
\text { learned in the program, and 58\% did not answer. }\end{array}$ \\
\hline S11 & $\begin{array}{l}16 \text { secondary } \\
\text { education } \\
\text { schools }\end{array}$ & $\begin{array}{l}2006 \text { male ado- } \\
\text { lescent athletes in } \\
\text { grades } 9-12\end{array}$ & $\begin{array}{l}\text { The athletes in the intervention group showed greater inten- } \\
\text { tion to intervene as bystanders to IPV situations (OR: } 0.12 \text {; } \\
95 \% \text { CI: } 0.003-0.24) \text { and intervention in situations that they } \\
\text { witnessed (OR: } 0.25 ; 95 \% \text { CI: } 0.13-0.38 \text { ). No significant } \\
\text { differences were identified in relation to gender equality and } \\
\text { recognition of abusive behaviors. }\end{array}$ \\
\hline S12 & $\begin{array}{l}\text { One univer- } \\
\text { sity }\end{array}$ & $\begin{array}{l}65 \text { adolescent and } \\
\text { young adult univer- } \\
\text { sity students }\end{array}$ & $\begin{array}{l}\text { The intervention group showed better results than the control } \\
\text { group in the post-intervention assessment and in the } 6 \text {-month } \\
\text { follow-up assessment. Knowledge and rejection of violence } \\
\text { improved }(p=0.007) \text { and remained over time. }\end{array}$ \\
\hline
\end{tabular}

The types of interventions, which are subdivided into three thematic categories, are described below.

\section{Multicomponent interventions}

Four studies were developed on multicomponent interventions. Gonzalez-Guarda, Guerra, Cummings, Pino, and Becerra (2015) assessed the results of a pilot study of a familyand school-based dating violence prevention program entitled: JOVEN/YOUTH: Juntos Opuestos a la Violence Entre Novios/Together Against Dating Violence. Ecodevelopmental and social cognitive theories were used to develop the study. The ecodevelopmental theory was used based on the idea that adolescents are in constant interaction with their peers, families, and, schools, which, in turn, are in constant interaction with other systems, being influenced by external factors. The social cognitive theory guided the development of activities that could contribute to changing behaviors and treating maladaptive behaviors among adolescents. The multicomponent intervention targeted 82 Latin-American students, aged 13 to 16 years, from a public school in the state of Florida, USA. Two groups were created, an intervention and a control group, with 41 participants each. The program included skill-building activities for students (six sessions), training for school staff (two sessions), and awareness-raising ses- sions for parents (two sessions). The resources used for the development of the sessions included pictures, videos, group discussion, and role-playing. There was a joint session for parents and students to practice their communication skills and negotiation of dating rules. Taylor, Mumford, and Stein (2015) evaluated the results of a program to prevent IPV and sexual harassment. A total of 2665 students of the $6^{\text {th }}$ and $7^{\text {th }}$ grade from 30 schools in New York City in the USA participated in the program. Students were divided into intervention and comparison groups. The intervention lasted between 6 and 10 weeks with classroom activities developed by teachers about the central topics of the program. During the same period, activities aimed at the school team were also developed. In addition to this aspect, this study brings an important contextual action, following WHO guidelines: it used hot spot mapping to identify unsafe areas in schools according to the adolescents.

The Start Strong: Building Healthy Teen Relationships initiative (Miller et al., 2014; Williams et al., 2015) is a multicomponent intervention aimed at reducing IPV, among other aspects. Its elements include prevention curricula, social marketing strategies, and policy and school environment changes. It was developed in eight schools in the USA: four were part of the intervention group and four of the control group. The program was evaluated by 1517 students aged 11 to 14 years. 
It should be noted that this intervention addressed and assessed not only IPV-related issues but other aspects such as child-parent communication; satisfaction and support in the dating relationship; reduced gender stereotypes and acceptance of dating violence; and bullying (Miller et al., 2015).

\section{Skill-building interventions}

Seven studies were developed on skills-building. The study of Murta et al. (2013) aimed to assess the effects of prevention of IPV and sexist and homophobic beliefs through the promotion of life skills among 60 adolescents of the city of Brasília, Brazil, aged 14 to 18 years. The intervention was based on the following life skills: self-awareness, critical thinking, effective communication, empathy, ability to manage emotions, decision-making, and problem-solving. The 27 adolescents in the intervention group participated in seven weekly 80 -minute meetings using the following resources: sharing of experience, role-playing, group discussion, exposure dialogue, music, and self-observation tasks. With the purpose of measuring the effectiveness of a IPV prevention program, Miller et al. (2012) evaluated 2,006 male athletes in grades 9-12 from 16 schools in California, USA, by dividing them into intervention and control groups. The Coaching Boys into Men program aims to change attitudes and behaviors towards dating violence in the male athlete population, particularly by increasing their skills for recognition of aggressive behaviors and improving their intention to intervene as bystanders to situations of violence. The intervention was delivered to athletes by their coaches who had received a 1-hour training and a kit with 11 training cards to guide their weekly 10-15 minute discussions with the athletes. A study sought to adapt the program to cricket athletes in India (Miller et al., 2014), which showed little change in the assessed patterns.

Póo and Vizcarra (2011) designed, implemented, and evaluated the IPV prevention program Construyendo una relación de pareja saludable (Building a Healthy Dating Relationship). It was based on the constructivist pedagogical paradigm and its notion of a subject as an active organization who seeks to adapt to the environmental stressors through the development of increasingly more sophisticated response schemes. The study included 65 Chilean university students (31 in the intervention group and 34 in the control group). The program aimed at preventing dating violence through the improvement of knowledge, skills, and attitudes of young people in 14 weekly sessions. The intervention called Bringing in the Bystander ${ }^{\odot}$ in-person program (Moynihan et al., 2015) was developed with 948 North-American students aged 18 to 24 years. The program aimed at increasing the involvement of students who are bystanders to sexual and relationship violence through active learning exercises.

The pilot study developed by Amar, Tuccinardi, Heislein, and Simpson (2015) refers to an intervention entitled Friends Helping Friends, whose goal is to teach older adolescents to recognize and intervene in situations of dating violence. It was based on the bystander education theory by Latané and Darley (1970), with a peer-based education approach for fighting against IPV. The study sample consisted of 101 female students, aged 18 to and 22 years, attending a private university in the northeast region of the USA, distributed into intervention and control groups. The participants received 12 hours of training consisting of exposure dialogue, role-playing, and management of group processes, with the purpose of improving the skills for identifying risk situations and intervening in these situations.

\section{Theater/role-playing interventions}

Theater interventions were used in the pilot study of Belknap, Haglung, Felzer, Pruszynski, and Schneider (2013). This study aimed to raise awareness about IPV and encourage non-violent responses in 66 Latino and Latina adolescents, with a mean age of 13 years, living in the state of Florida, USA. The intervention was based on the Theater of the Oppressed and included two 15-minute plays, which were written, directed, and performed by four university students and a professional theater director. During these plays, the intention was that the adolescents in the audi- 
ence would relate to the characters and question themselves about IPV situations and, consequently, change their behaviors. The results were significantly positive.

As it has been shown above, the programs focused on three main interventions, which, overall, showed homogeneous results, regardless of their methodological designs. Different instruments were used to assess the programs. The questionnaires used in these studies included different scales with several ratings, showing the difficulty of detection, but also the great interest and concern to encompass several IPV-related aspects.

Four intervention programs were assessed longitudinally, ranging from a small to a moderate effect: the Coaching Boys into Men program (Miller et al., 2012; Miller et al., 2013; Miller et al., 2014); the Start Strong initiative (Miller et al., 2015); the JOVEN/ YOUTH program (Gonzalez-Guarda et al., 2015); and the Bringing in the Bystander ${ }^{\circ}$ in-person program (Moynihan et al., 2015). In the Coaching Boys into Men program, the positive changes observed immediately after the follow-up were not maintained until the 12-month follow-up because the athletes had left the team several months before. The Start Strong initiative had better results, because, in the long term, there was also an improvement for the control group, associated with the involvement of staff and parents in the intervention. The JOVEN/YOUTH program did not maintain the statistically significant positive effects over time. Finally, the Bringing in the Bystander in-person program was presented as the first study up until then to find positive behavioral changes 12 months after an intervention with bystanders for IPV prevention. This aspect was strongly associated with the importance of working with peers, particularly regarding the readiness to help and the opportunity to engage (Moynihan et al., 2015). Few studies $(33.3 \% ; n=4)$ used theoretical frameworks to assist and encourage reflection on the development and delivery of the intervention program (i.e. how to implement the intervention). In a systematic review of primary and secondary prevention programs for sexual violence, the authors considered the need to create high-intensity programs changing complex behaviors such as violence (DeGue et al., 2014).

As already discussed, the study subjects in these articles were adolescents; however, some studies highlighted peculiarities in the samples $(58.3 \% ; n=7)$. A study implemented the intervention in Cuban descendent adolescents who lived in the USA. This program was developed in English and Spanish (Gonzalez-Guarda et al., 2015). The intervention proved to have a stronger effect on boys than on girls regarding IPV victimization and perpetration. There may also be important developmental differences between Cuban-American adolescent males and females, which may have varying effects on IPV (Gonzalez-Guarda et al., 2015).

Another study in this review also directed the program to Latino/a adolescents (Belknap et al., 2013), with the main justification that attitudes targeted at and correlated with IPV were influenced by cultural views of gender roles and differed by gender and levels of acculturation. Latino/a adolescents showed more traditional views of gender roles and greater acceptance of IPV (Ulloa, Jaycox, Skinner, \& Orsbun, 2008); however, some Hispanic cultural beliefs have served as a protective factor for violence (Enriquez, Kelly, Cheng, Hunter, \& Mendes, 2012). Violence prevention programs should be accessible to all and use a social and ecological model that takes into account individual, relational, community, and social factors (WHO, 2014).

In addition, in the study of Belknap et al. (2013), adolescents showed greater acceptance of female-on-male violence than maleon-female violence. This result may have been influenced by the theater play that portrayed the male partner as aggressor and the female partner as victim, which was described as a limitation of the study.

We tried not to work with specific audiences; however, one study (Taylor et al., 2015) compared the difference in the effectiveness of the program among adolescents with a history of dating violence or sexual abuse. The results did not indicate a variation in the case of adolescents with a history of IPV or sexual abuse. In addition, another study (Williams et al., 2015) showed that students at highest risk for IPV, sexual harassment, and bullying were 
more likely to respond to interventions.

The studies focused their interventions, as already indicated, on $7^{\text {th }}$-grade adolescents (around the age of 12 to 13 years; 33.2\%; $n=4)$. These are innovative initiatives since interventions are traditionally addressed to older adolescents. Adolescence is a critical period because of the transition and initiation of affective relationships, and the continued and strengthened emphasis on initiatives aimed to reduce IPV acceptance and gender stereotypes in early adolescence may decrease IPV throughout life (Miller et al., 2015).

It should be noted that, despite the lower rates of severe violence among younger adolescents found in the literature, this fact may be related to the use of measures developed for older adolescents. Studies indicate that the nature and the meanings of violence are different among younger adolescents (Pelligrini \& Long, 2003).

Another special characteristic of the studies was the focus on bystanders (Miller et al., 2012; Moynihan et al., 2015; Miller et al., 2013). Attitudes that legitimize the perpetuation of IPV have been identified as modifiable risk factors; bystander or peer interventions are particularly relevant in adolescence, which is a period when friends/ peers are important (McMahon, 2010). Prior knowledge of IPV, being a woman, and a favorable context emerge as factors with a positive impact on bystander attitudes.

In addition to the above, many results were statistically correlated with the sense of support and satisfaction in teen dating relationships, which was particularly discussed by Miller et al. (2015). Studies have revealed that relationships with positive affect are associated with lower victimization and perpetuation of IPV; reduced alcohol consumption and drug use; and less emotional problems (Orpinas, Hsieh, Song, Holland, \& Nahapetyan, 2013; Collins, Welsh, \& Furman, 2009).

Thus, although there are some recommendations, the literature still does not allow for the definition of interventions that have proven to be effective in all aspects related to IPV prevention. However, interventions should seek to focus on several aspects of these adolescents' lives in a contextual manner by addressing topics that are transversal to the prevention of various types of violence affecting them.

The main limitations of the study include the large number of descriptors used in the literature search, the lack of terminological standardization within the topic, the timeframe, and the exclusion of gray literature. The authors decided to include only scientific articles published in the past 5 years, possibly seeking to obtain data with greater scientific validity, as well as an updated perspective on the phenomenon. In addition, we underline the respect for the ethical-legal principles in all analyzed studies.

\section{Conclusion}

This study included the latest scientific articles on IPV prevention interventions, which can be multicomponent interventions, skill-building interventions, and theater/role-playing interventions. The results showed no significant differences. This study has pointed to important implications to clinical practice and research in this area, namely: (1) the need for a theoretical framework to support interventions, from their design to data analysis; (2) the need for approaches that take into account contextual specificities (social, cultural, economic, family); (3) the importance of interventions targeting changes in bystanders and contexts where adolescents are inserted; (4) the need to address intimate relationships other than heterosexual relationships, as well as non-steady intimate relationships; (5) the need for interventions that address parental communication; (6) the importance of control groups for data reliability and elimination of biases and conflicting situations.

This review also brought to light aspects which require further studies to be conducted, namely: (1) studies on gender, developmental, and cultural differences for clarification of IPV prevention programs; (2) studies on the design of scales that provide reliable measures for younger adolescents, particularly regarding the types of violence experienced; (3) studies that 
associate the responses to the intervention with prior knowledge; (4) studies on interventions focused on the promotion of healthy relationships.

Financial Support: Fundação de Amparo à Pesquisa do Estado de São Paulo (São Paulo Research Foundation), process no. 2015/14668-9.

\section{References}

Centers for Disease Control and Prevention. (2016). Understanding teen dating violence. Fact Sheet. Atlanta, USA: Author. Retrieved from https:// www.cdc.gov/violenceprevention/pdf/teen-datingviolence-factsheet-a.pdf

Collins, W. A., Welsh, D. P., \& Furman, W. (2009). Adolescent romantic relationships. Annual Review of Psychology, 60, 631-652. doi: 10.1146/annurev. psych.60.110707.163459

DeGue, S., Anne Valle, L., Holt, M.K., Massetti, G., Matjoska, J. L., \& Teten Tharp, A. (2014). A systematic review of primary prevention strategies for sexual violence perpetration. Aggression and Violence Behavior, 19(4), 346-362. doi:10.1016/j. avb.2014.05.004

Ellsberg, M., Arango, D.J., Morton, M., Gennari, F., Kiplesund, S., Contreras, M., \& Watts, C. (2015). Prevention of violence against women and girls: What does the evidence say? Lancet, 385(9977), 1555-1566. doi: 10.1016/S0140-6736(14)61703-7

Enriquez, M., Kelly, P., Cheng, A. L., Hunter, J., \& Mendes, E. (2012). An intervention to address interpersonal violence among low-income midwestern Hispanic-American teens. Journal of Immigrant and Minority Health, 14(2), 292-299. doi:10.1007/s10903-011-9474-5

Latane, B., \& Darley, J. M. (1970). The unresponsive bystander: Why doesn't he help. New York: AppletonCentury-Crofts.
Malta, D. C., Mascarenhas, M. D., Dias, A. R., Prado, R. R., Lima, C. M., Silva, M. M., \& Silva Junior, J. B. (2015). Situations of violence experienced by students in the state capitals and the Federal District: Results from the national adolescent school-based health survey (PeNSE 2012). Revista Brasileira de Epidemiologia, 17(1), 158-171. doi: 10.1590/18094503201400050013.

McMahon, S. (2010). Rape myth beliefs and bystander attitudes among incoming college students. Journal of American college health, 59(1), 3-11. doi: http:// doi.org/10.1080/07448481.2010.483715

Mendes, K. S., Silveira, R. C., \& Galvão, C. M. (2008). Revisão integrativa: Método de pesquisa para a incorporaçáo de evidências na saúde ena enfermagem. Texto e Contexto Enfermagem, 17(4), 758-764. doi: 10.1590/S0104-07072008000400018

Orpinas, P., Hsieh, H. L., Song, X., Holland, K., \& Nahapetyan, L. (2013). Trajectories of physical dating violence from middle to high school: Association with relationship quality and acceptability of aggression. Journal of Youth and Adolescence, 42(4), 551-565. doi: 10.1007/s10964012-9881-5

Pelligrini, A. D., \& Long, J. D. (2003). A sexual selection theory longitudinal analysis of sexual segregation and integration in early adolescence. Journal of Experimental Child Psychology, 85(3), 257-278. doi: 10.1016/S0022-0965(03)00060-2

Ulloa, E., Jaycox, L., Skinner, S., \& Orsburn, M. (2008). Attitudes about violence and dating among Latino/a boys and girls. Journal of Ethnic \& Cultural Diversity in Social Work, 17(2), 157-176. doi: $10.1080 / 15313200801941721$

World Health Organization. (2014). Global status report on violence prevention. Geneva, Switzerland: Author.

World Health Organization. (2017). Global accelerated action for the health of adolescents (AA-HA!): Guidance to support country implementation. Geneva, Switzerland: Author. 
